ORIGINAL ARTICLE / ARTIGO ORIGINAL

Labor in early life, vulnerability for health in Brazilian schoolchildren: National Adolescent School-based Health Survey (PeNSE 2012)

\title{
Trabalho precoce, marcador de vulnerabilidades para saúde em escolares brasileiros: Pesquisa Nacional de Saúde do Escolar (PeNSE 2012)
}

\author{
Luana Giatti',"I, Maryane Oliveira Campos", Claudio Dutra Crespo"',
} Silvania Suely Caribé de Araújo Andrade ${ }^{\mathrm{Iv}, \mathrm{v}}$, Sandhi Maria Barreto"

\begin{abstract}
Objective: This study describes exposure labor among Brazilian $9^{\text {th }}$ grade students from public and private schools and investigates socio-demographic characteristics, behaviors, violent situations and psychosocial factors associated with labor among adolescents. Methods: The present study included 108,984 students from the National Adolescent School-based Health Survey carried out in 2012. Variables were grouped into sociodemographic characteristics, behavioral factors, violent situations and psychosocial aspects. Associations between labor and several health risk variables were identified by multiple logistic regression analysis, after adjustment for sex and age. Results: Approximately $13 \%$ of the students reported having a job: $17.4 \%$ of them were male. The chance of working was lower between females and individuals whose fathers' have incomplete superior education. Students who worked had greater chances to smoke $(\mathrm{OR}=2.26 ; 95 \% \mathrm{CI} 2.04-2.51)$, drink alcohol, use illicit drugs $(\mathrm{OR}=2.63 ; 95 \% \mathrm{CI} 2.29-3.02)$, drive motorized vehicles $(\mathrm{OR}=2.15 ; 95 \% \mathrm{CI} 2.03-2.27)$, have sexual intercourse $(\mathrm{OR}=2.10 ; 95 \% \mathrm{CI} 1.99-2.24)$, suffer physical violence $(\mathrm{OR}=1.57 ; 95 \% \mathrm{CI} 1.46-1.68)$, engage in fights $(\mathrm{OR}=1.65 ; 95 \% \mathrm{CI} 1.55-1.76)$, feel lonely $(\mathrm{OR}=1.26 ; 95 \% \mathrm{CI} 1.17-1.36)$ and report sleeping problems $(\mathrm{OR}=1.46 ; 95 \% \mathrm{CI} 1.34-1.60)$. They also have lower chances of having close friends $(\mathrm{OR}=0.78$; $95 \% \mathrm{CI} 0.68-0.90)$. Conclusion: The prevalence of labor among students is high. Socioeconomical disadvantages increase the chances of early working. Early working is also associated to health damaging behavior, violent situations, sleeping problems, and social isolation. Adolescents who study and work experiment expositions that may affect distinct health dimensions and perpetuate disadvantages over lifetime.
\end{abstract}

Keywords: Child labor. Risk factors. Behavioral risk factors. Violence. Psychosocial impact. Students.

ISchool of Nutrition, Universidade Federal de Ouro Preto - Ouro Preto (MG), Brazil.

"School of Medicine, Universidade Federal de Minas Gerais - Belo Horizonte (MG), Brazil.

'"Brazilian Institute of Geography and Statistics - Rio de Janeiro (MG), Brazil.

vMinistry of Health - Brasília (DF), Brasil.

vSchool of Public Health, Universidade de São Paulo - São Paulo (SP), Brazil.

Corresponding author: Luana Giatti. Escola de Nutrição. Universidade Federal de Ouro Preto. Programa de Pós-Graduação em Saúde e Nutrição. Campus Universitário, Morro do Cruzeiro, s/n. CEP: 35.400-000, Ouro Preto, MG, Brasil. E-mail: luana.giatti@gmail.com Conflict of interests: nothing to declare - Financing source: The National Council for Scientific and Technological Development (CNPq) (Scholarship n. 300159/99-4 e 312371/13-6). 
RESUMO: Objetivos: Descrever a prevalência de trabalho em estudantes da $9^{\text {a }}$ série do ensino fundamental de escolas públicas e privadas brasileiras e investigar as características sociodemográficas, comportamentos relacionados à saúde, situações de violência e aspectos psicossociais associados ao trabalho. Métodos: Foram utilizados dados da PeNSE 2012 e investigadas associações independentes entre características sociodemográficas e trabalho e a associação entre trabalho e fatores comportamentais e de proteção à saúde, situações de violência e aspectos psicossociais, ajustadas por sexo e faixa etária. Utilizou-se regressão logística binária para obter o Odds Ratio e seu intervalo de confiança de 95\%. Resultados: Foram incluídos 108.984 estudantes. Deste total, 13,1\% trabalhavam: 17,4\% eram meninos e $22,1 \%$ tinham 16 anos ou mais. A chance de trabalhar foi menor entre as meninas e entre aqueles com escolaridade paterna com nível universitário incompleto, e maior entre alunos das escolas públicas. Após ajuste por sexo e idade, os alunos que trabalhavam tiveram maior chance de tabagismo (OR = 2,26; IC95\% 2,04-2,51), consumo de álcool, drogas ilícitas (OR = 2,63; IC95\% 2,29 - 3,02), direção de veículo motorizado (OR = 2,15; IC95\% 2,03 - 2,27), relação sexual (OR = 2,10; IC95\% 1,99 - 2,24), sofrer agressão física (OR = 1,57; IC95\% 1,46 - 1,68), envolvimento em briga $(\mathrm{OR}=1,65$; IC95\% 1,55 - 1,76), sofrer ferimentos, sentir-se só e dificuldade em dormir, além de menor chance de ter amigos próximos $(\mathrm{OR}=0,78$; IC95\% 0,68 - 0,90). Conclusão: A prevalência de trabalho é elevada. Desvantagens socioeconômicas aumentam a chance de trabalho precoce. Este também está associado a comportamentos prejudiciais à saúde, situações de violência, problemas de sono e isolamento social. Adolescentes que estudam e trabalham vivenciam exposições que podem afetar distintas dimensões da saúde e perpetuar desvantagens ao longo da vida.

Palavras chave: Trabalho de adolescentes. Fatores de risco. Fator de Risco Comportamental. Violência. Impacto psicossocial. Estudantes.

\section{INTRODUCTION}

The initiation of children and adolescents in labor is a global problem that occurs mostly in poorer countries, but it is also relevant in middle-income countries. The 2012 Report by the International Labor Organization (ILO) showed that the number of children and adolescents who worked declined 33\% from 2000 to 2012. Despite this major reduction, working in this stage of life is still a great social challenge. In 2012, about 265 million children and adolescents aged 5 to 17 years old (16.7\%) were economically active, almost 168 million (10.6\%) worked in positions that were not in accordance with the minimum established age, and 85 million (5.4\%) worked in positions considered to be dangerous or with potential damaging effects ${ }^{1}$.

Brazil has obtained expressive results for fighting labor involving children and adolescents. In $2001,12.7 \%$ of the children aged 5 to 17 years old were inserted in economic activities; In 2012 , this percentage reached $8.3 \%{ }^{3}$, therefore, a $35 \%$ reduction in 11 years. The specific programs to eradicate and prevent labor in this stage of life, the improving economic situation of the families and the conditions imposed by income transfers programs contributed with these results ${ }^{4}$. 
The early exposure to work has been more frequent among more vulnerable socioeconomic groups, in families whose parents have low schooling and more children, besides being influenced by social and cultural environments ${ }^{4-7}$. There is a two-way relationship between poverty and child labor, because the latter can perpetuate the former, once these children tend to become adults with lower professional qualification and, consequently, lower earnings in the work market ${ }^{8}$.

The early stages of life, including adolescence, are critical periods for the formation and development of the individual, which have a strong influence on life in general ${ }^{9}$. The exposure to labor can have a negative effect on physical and psychosocial development by interfering in school attendance and performance, as well as in leisure, in relationships with relatives and with peers, which provide a healthy environment for psychological and social formation ${ }^{10}$. These effects seem to be more damaging the lower the age of exposure to labor ${ }^{11}$. On the other hand, it is suggested that labor can have positive effects by favoring the acquisition of discipline, responsibility and self-confidence ${ }^{12}$.

The early exposure to labor can also be more damaging when associated to the exposure to toxic substances, heavy machinery, physical and emotional violence ${ }^{13,14}$. Studies pointed out to the association between labor among children and adolescents and musculoskeletal disorders ${ }^{11,14}$, behavioral issues, such as aggressiveness, anxiety and depression ${ }^{15}$, sleeping problems $^{10}$, smoking ${ }^{8,16}$, and use of illicit drugs.

A few studies investigated the relationship between early exposure to labor and health. Obtaining information from children, family members and employers about insertion in the work market is a challenge, which may explain the lack of studies ${ }^{7}$. The main goal of the National Adolescent School-Based Health Survey (PeNSE) is to monitor the main risk and protective factors for the health of students. The second edition, carried out in 2012, included two questions related to insertion in labor ${ }^{17}$. The objective of this study was to verify the proportion of students who reported working, the sociodemographic characteristics that are independently associated with the work of students and to analyze if the report of working is associated with risk and protective health behaviors, violent situations and unfavorable psychosocial aspects.

\section{METHODS}

This study used data from the National Adolescent School-Based Health Survey (PeNSE), conducted by the Ministry of Health, together with IBGE, in 2012. PeNSE was conducted with a sample of $9^{\text {th }}$ graders, from elementary school, in daytime periods of public and private schools, representing the country, its five macroregions and the 26 Brazilian State capitals and the Federal District ${ }^{17}$.

In order to calculate the sample in each geographic stratum, a 50\% prevalence of exposure, maximum error of $3 \%$ and $95 \%$ confidence interval $(95 \% \mathrm{CI})$ were considered. The sampling plan defined 27 geographic strata corresponding to all State capitals and the 
Federal District, and other five geographic strata corresponding to the five macroregions containing the other cities. The sample of each geographic stratum was proportionally allocated to the number of schools, according to administration (private and public). In the strata formed by capitals and the Federal District, a two-stage cluster sample was selected. Schools were in the first stage; the eligible classrooms in the selected schools were in the second stage. In strata formed by the other cities, which were grouped according to criteria related to homogeneity and geographic proximity, the sample was developed in three stages: in the first stage, there was the group of cities; in the second stage, there were schools; and in the third stage, the eligible classrooms.

Afterwards, all students attending the selected classrooms were invited to answer the questionnaire. Then, a weighing factor was used in the sample so it could represent all enrolled $9^{\text {th }}$ graders who attend classes regularly ${ }^{17}$. The $9^{\text {th }}$ grade was chosen because the students were considered to be able to answer the self-applicable questionnaire, since they were more prone to being exposed to several risk factors and because it would be possible to compare these data with systems from other countries ${ }^{18}$.

For data collection, a self-applied structured questionnaire was used, which included sociodemographic characteristics, risk and protective behaviors for health and other factors. Students answered the questionnaire in a smartphone. The participation in the study was voluntary, with the non-response possibility. No information that could identify the student was collected, and data related to the school were confidential, therefore, not shown in the data base. The research project was approved by the National Research Ethics Committee CONEP, n. 16.805. The detailed methodology is described in PeNSE, $2012^{17}$.

\section{STUDIED VARIABLES}

The variable work situation (does not work, non-paid work, paid work) was obtained by two questions: "Do you currently have a job, position or business?", and "Are you paid for this job, position or business?". Afterwards, the categories "working without wages" and "working with wages" were grouped, and the variable work (no, yes) was used to investigate the associations with sociodemographic factors, behavioral risk factors, violent situations and psychosocial aspects.

The analyzed sociodemographic characteristics of students were: sex, age group ( $\leq 13$ years old, $14-15$ years old, 16 years old or more), ethnicity/color (white, black, yellow, mulatto, indigenous), maternal schooling (incomplete elementary school - including mothers who did not attend school and the ones who did not complete elementary school, incomplete high school, incomplete higher education, complete higher education, could not inform it), paternal schooling (incomplete elementary school - including fathers who did not attend school and the ones who did not complete elementary school, incomplete high school, incomplete higher education, complete higher education, could not inform it), school administration (private, public) and macroregion of residency (Southeast, North, 
Northeast, Center-West, South). Students who could not inform maternal and paternal schooling remained in the analysis, since they represented $18.4 \%$ and $23.7 \%$ of the total, respectively.

Variables related to health were grouped into:

- Risk/protective behaviors of the student: current smoker, defined as having smoked in the past 30 days (no, yes); alcohol consumption in the past 30 days (no, once or more); use of illicit drugs - marijuana, cocaine, crack, solvent-based glue, ether and chloroform substances, poppers, ecstasy or others - in the past 30 days (no, once or more); having had sexual intercourse in the past 12 months (no, yes); having driven a motorized vehicle in the past 30 days (no, once or more); having practiced physical activities during leisure time in the past seven days (up to 4 days, 5 days or more).

- Violent situations: report of physical aggression in the past 12 months (none, once or more); being involved in fights in the past 12 months (none, once or more); being injured in the past 12 months (none, once or more).

- Psychosocial aspects: number of close friends (none, one or more); frequency of feeling lonely in the past 12 months (never/rarely, sometimes/most of the time/ always); frequency of having difficulty sleeping in the past 12 months (never/ rarely, sometimes/most of the time/always).

\section{ANALYSIS}

Work was described (does not work, working without wages, working with wages) according to sex, age group, ethnicity/color, school administration and macroregion of residency. Afterwards, the variable work status was transformed into a binary variable (no, yes) and the prevalence of work was estimated according to all of the analyzed sociodemographic characteristics. The association between sociodemographic and work characteristics was verified by the Pearson's $\chi^{2}$ test, with a 0.05 significance level. In order to identify the sociodemographic variables that are independently associated with work, the Odds Ratio (OR) was obtained; the $95 \% \mathrm{CI}$ was obtained by the use of a multiple logistic regression model. The multivariate analysis included the variables that presented 0.20 significance level on the univariate analysis.

Afterwards, the prevalence of risk and protective behavioral factors was estimated, as well as the prevalence of violent situations and psychosocial aspects among those who work and those who do not. The association between work and these variables was assessed by the Pearson's $\chi^{2}$ test, with a 0.05 significance level. The magnitude of the association between work and the variables related to health was estimated by OR $(95 \% \mathrm{CI})$, with adjustment for sex and age group obtained by logistic regression.

The analysis was conducted in the software Stata (version 11), using the "svy" procedure (with weighing factors), which is adequate to analyze data obtained by a complex sampling plan. 


\section{RESULTS}

Out of the 109,104 students who participated in PeNSE, 108,984 were included in this analysis, and 120 were excluded because they did not have information about work. Out of these, $52.2 \%$ were female, $63.4 \%$ were between 14 and 15 years old, $82.8 \%$ attended public schools, $13.1 \%$ reported working at the time of the study, and $8.9 \%$ worked with earnings. In the capitals and in the Federal District, the percentage of working students was of $12 \%$, out of which $10.8 \%$ earned a earning.

The distribution of students according to work status (does not work, paid work and non-paid work) and sex, age group, ethnicity/color, school administration and macroregion of residency presented statistically significant differences. The percentage of students with wages was higher in public schools than in private ones $(89.4 \%$ and 10.6\%) (Table 1).

The prevalence of work (paid and non-paid) was higher among boys $(17.4 \%$; $<<0.00001)$ aged more than 16 years old $(22.9 \%$; $\mathrm{p}<0.00001)$, those who reported being indigenous and yellow $(15.5 \%$ and $15.2 \% ; \mathrm{p}<0.0001)$, the ones who informed maternal and paternal schooling up to the stage of incomplete high school, the ones studying in public schools and those living in the South and Center-West regions (Table 2).

The results of the multiple analysis showed that, in comparison to adolescents who did not work, the chances of working increased with the increment in age group. The chances of working were lower among girls $(\mathrm{OR}=0.50 ; 95 \% \mathrm{CI} 0.47-0.53)$ and among students whose parents had incomplete higher education $(\mathrm{OR}=0.90 ; 95 \% \mathrm{CI} 0.83-0.97)$ in comparison to those whose parents had up to incomplete elementary school. The chances of working were higher among those attending public schools $(\mathrm{OR}=1.51 ; 95 \% \mathrm{CI} 1.37-1.67)$ in comparison to the ones attending private schools, participants who reported having yellow skin $(\mathrm{OR}=1.26$; $95 \% \mathrm{CI} 1.10-1.45)$ or being indigenous $(\mathrm{OR}=1.25 ; 95 \% \mathrm{CI} 1.08-1.46)$ in relation to the ones who mentioned white color and living in the South, Center-West and North regions in comparison to those living in the Southeast (Table 2).

The description of prevalence rates of behavioral risk factors, violent situations and psychosocial aspects according to work status is presented in Table 3 . The prevalence of all behavioral factors was higher among the ones who worked, as well as the prevalence in the report of exposure to violent situations. The proportion of students who reported having no close friends $(18.0 \% ; \mathrm{p}<0.0001)$, feeling lonely in the past 12 months $(13.9 \%$; $\mathrm{p}=0.02)$ and having difficulty sleeping in the past 12 months $(16.1 \%$; $<<0.0001)$ was higher among those who worked. The proportion of people who practiced physical activities for leisure for five days a week or more was higher among the ones who worked $(16.1 \%$; $<<0.0001)$.

The results of the analysis adjusted for sex and age group showed that, in comparison to students who did not work, those who worked had higher chances of smoking $(\mathrm{OR}=2.26$; $95 \% \mathrm{CI} 2.04-2.51)$, consuming alcohol $(\mathrm{OR}=1.89 ; 95 \% \mathrm{CI} 1.78-2.00)$, using illicit drugs $(\mathrm{OR}=2.63 ; 95 \% \mathrm{CI} 2.29-3.02)$, driving a motorized vehicle $(\mathrm{OR}=2.15 ; 95 \% \mathrm{CI} 2.03-2.27)$ 
and having had sexual intercourse in the past 12 months (OR $=2.10 ; 95 \% \mathrm{CI} 1.99-2.24)$. They also presented higher chances of having suffered physical aggression $(\mathrm{OR}=1.57$; $95 \%$ CI $1.46-1.68)$, having been involved in fights ( $\mathrm{OR}=1.65 ; 95 \% \mathrm{CI} 1.55-1.76)$, having been injured $(\mathrm{OR}=1.73 ; 95 \% \mathrm{CI} 1.60-1.87)$, as well as having felt lonely $(\mathrm{OR}=1.26 ; 95 \% \mathrm{CI}$ $1.17-1.36)$, and having had difficulty sleeping in the past 12 months $(\mathrm{OR}=1.46 ; 95 \% \mathrm{CI}$

Table 1. Distribution of $9^{\text {th }}$ grade students according to work status and sociodemographic characteristics. Brazil, National Adolescent School-based Health Survey, 2012.

\begin{tabular}{|c|c|c|c|}
\hline & $\begin{array}{c}\text { Does not work } \\
\begin{array}{c}n=53.929 \\
(88.1 \%)\end{array}\end{array}$ & $\begin{array}{l}\text { non-paid work } \\
n=709(1.14 \%)\end{array}$ & $\begin{array}{c}\text { paid work } \\
\mathrm{n}=6.444(10.8 \%)\end{array}$ \\
\hline \multicolumn{4}{|l|}{ Sex* } \\
\hline Male & $45.1(43.3-47.7)$ & $59.8(56.4-63.0)$ & $63.9(62.1-65.6)$ \\
\hline Female & $54.5(52.3-56.8)$ & $40.2(37.0-43.6)$ & $36.1(34.7-38.0)$ \\
\hline \multicolumn{4}{|c|}{ Age group (years)* } \\
\hline$<13$ & $24.1(18.6-30.7)$ & $20.3(16.3-25.0)$ & $14.5(9.9-20.6)$ \\
\hline $14-15$ & $64.1(61.7-66.3)$ & $58.3(53.5-62.9)$ & $63.4(61.9-64.9)$ \\
\hline$>16$ & $11.8(7.9-17.3)$ & $21.5(15.8-28.6)$ & $22.1(16.9-28.4)$ \\
\hline \multicolumn{4}{|c|}{ Ethnicity/skin color* } \\
\hline White & $37.0(31.9-42.4)$ & $36.6(27.3-47.0)$ & $36.8(31.8-42.2)$ \\
\hline Black & $13.2(10.8-16.0)$ & $15.4(14.2-16.7)$ & $13.4(13.0-15.8)$ \\
\hline Yellow & $4.0(3.4-4.7)$ & $3.9(2.1-6.1)$ & $4.1(3.8-4.9)$ \\
\hline Mulatto & $42.4(39.4-45.4)$ & $40.7(31.6-50.1)$ & $42.2(37.2-45.6)$ \\
\hline Indigenous & $3.4(2.8-4.3)$ & $3.4(2.1-5.5)$ & $4.2(3.3-5.5)$ \\
\hline \multicolumn{4}{|l|}{ School* } \\
\hline Private & $18.1(13.7-23.5)$ & $18.1(13.9-23.3)$ & $10.6(8.3-13.5)$ \\
\hline Public & $81.9(76.5-86.3)$ & $81.9(76.8-86.2)$ & $89.4(86.5-91.7)$ \\
\hline \multicolumn{4}{|c|}{ Macroregion - residency* } \\
\hline Southeast & $45.1(42.3-48.0)$ & $41.8(36.4-47.3)$ & $38.7(34.3-43.2)$ \\
\hline North & $7.8(7.2-8.4)$ & $9.0(7.9-10.3)$ & $8.9(7.6-10.2)$ \\
\hline Northeast & $24.4(23.6-27.3)$ & $25.0(20.3-30.4)$ & $25.3(22.6-26.8)$ \\
\hline Center-West & $7.7(6.3-9.3)$ & $8.8(7.2-10.7)$ & $9.5(8.5-10.5)$ \\
\hline South & $14.0(12.2-16.1)$ & $15.4(12.1-19.5)$ & $14.6(13.4-158)$ \\
\hline
\end{tabular}

*Statistically significant difference $(p<0.05)$. 
Table 2. Prevalence of work according to sociodemographic characteristics in $9^{\text {th }}$ grade students and adjusted Odds Ratio. Brazil, National Adolescent School-based Health Survey, 2012.

\begin{tabular}{|c|c|c|c|c|}
\hline & Working (\%) & $p$-value & OR & $95 \% \mathrm{Cl}$ \\
\hline \multicolumn{5}{|l|}{ Sex } \\
\hline Male & 17.4 & $<0.00001$ & 1.00 & \\
\hline Female & 9.2 & & 0.50 & $0.47-0.53$ \\
\hline \multicolumn{5}{|l|}{ Age group (years) } \\
\hline$<13$ & 8.6 & $<0.00001$ & 1.0 & \\
\hline $14-15$ & 12.9 & & 1.50 & $1.38-1.62$ \\
\hline$>16$ & 22.1 & & 2.58 & $2.34-2.85$ \\
\hline \multicolumn{5}{|l|}{ Skin color } \\
\hline White & 12.6 & $<0.00001$ & 1.00 & \\
\hline Black & 14.3 & & 1.03 & $0.94-1.13$ \\
\hline Yellow & 15.2 & & 1.26 & $1.10-1.45$ \\
\hline Mulatto & 12.9 & & 1.01 & $0.94-1.08$ \\
\hline Indigenous & 15.5 & & 1.25 & $1.08-1.46$ \\
\hline \multicolumn{5}{|l|}{ Maternal schooling } \\
\hline Incomplete elementary school & 14.3 & $<0.00001$ & & \\
\hline Incomplete high school & 14.4 & & & \\
\hline Incomplete higher education & 12.6 & & & \\
\hline Complete higher education & 10.8 & & & \\
\hline Could not inform & 11.9 & & & \\
\hline \multicolumn{5}{|l|}{ Escolaridade paterna } \\
\hline Incomplete elementary school & 14.9 & $<0.00001$ & 1.00 & \\
\hline Incomplete high school & 14.6 & & 1.02 & $0.94-1.12$ \\
\hline Incomplete higher education & 11.9 & & 0.90 & $0.83-0.97$ \\
\hline Complete higher education & 11.5 & & 0.97 & $0.85-1.09$ \\
\hline Could not inform & 11.2 & & 0.80 & $0.74-0.87$ \\
\hline \multicolumn{5}{|l|}{ School administration } \\
\hline Private & 8.6 & $<0.00001$ & 1.00 & \\
\hline Public & 14.1 & & 1.51 & $1.37-1.67$ \\
\hline \multicolumn{5}{|l|}{ Macroregion of residency } \\
\hline Southeast & 11.6 & $<0.00001$ & 1.00 & \\
\hline North & 14.7 & & 1.14 & $1.06-1.23$ \\
\hline Northeast & 12.8 & & 1.05 & $0.97-1.13$ \\
\hline Center-West & 15.7 & & 1.34 & $1.25-1.44$ \\
\hline South & 16.4 & & 1.52 & $1.40-1.64$ \\
\hline
\end{tabular}

OR $(95 \% \mathrm{Cl})$ adjusted by all variables, except for maternal schooling $(p>0.05)$. 
Table 3. Prevalence of behavioral factors, violent situations and psychosocial aspects according to work, and adjusted odds ratio for age and sex in $9^{\text {th }}$ grade students. Brazil, National Adolescent School-based Health Survey, 2012.

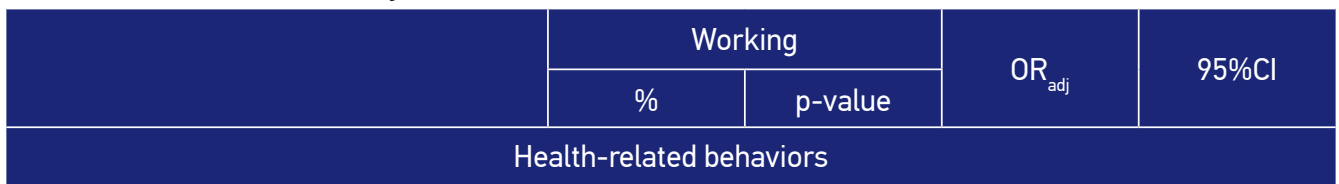

Current smoker

\begin{tabular}{l|l|l|l|l}
\hline No & 12.4 & & 1.00 & \\
\hline Yes & 26.1 & $<0.0001$ & 2.26 & $2.04-2.51$ \\
\hline Alcohol consumption in the past 30 days & & & \\
\hline No & 10.9 & & 1.00 & \\
\hline Once or more & 19.4 & $<0.0001$ & 1.89 & $1.78-2.00$ \\
\hline Use of illicit drugs in the past 30 days & & & & \\
\hline No & 12.7 & & 1.00 & \\
\hline Once or more & 30.0 & $<0.0001$ & 2.63 & $2.29-3.02$ \\
\hline Sexual intercourse in the past 12 months & & & 1.00 & \\
\hline No & 10.4 & & 2.10 & $1.99-2.24$ \\
\hline Yes & 23.2 & $<0.0001$ & & \\
\hline Driving a motorized vehicle in the past 30 days & 9.8 & & 2.15 & $2.03-2.27$ \\
\hline No & 22.0 & $<0.0001$ & \\
\hline Once or more & & & \\
\hline
\end{tabular}

Physical activity in leisure in the past 7 days

\begin{tabular}{l|l|l|l|l|}
\hline Up to 4 days & 12.1 & & 1.00 & \\
\hline 5 days or more & 16.1 & $<0.0001$ & 1.26 & $1.19-1.34$ \\
\hline
\end{tabular}

\section{Violent situations}

Physical aggression in the past 12 months

\begin{tabular}{l|l|l|l|l}
\hline None & 12.2 & & 1.00 & \\
\hline Once or more & 17.8 & $<0.0001$ & 1.57 & $1.46-1.68$ \\
\hline
\end{tabular}

Fights in the past 12 months

\begin{tabular}{l|l|l|l|l}
\hline None & 14.4 & & 1.00 & \\
\hline Once or more & 19.5 & $<0.0001$ & 1.65 & $1.55-1.76$ \\
\hline
\end{tabular}

Being injured in the past 12 months

\begin{tabular}{l|l|l|l|l}
\hline None & 12.1 & & 1.00 & \\
\hline Once or more & 20.7 & $<0.0001$ & 1.73 & $\begin{array}{c}1.60-1.87 \\
\text { continue... }\end{array}$
\end{tabular}


Table 3. Continuation.

\begin{tabular}{|c|c|c|c|c|}
\hline & \multicolumn{2}{|c|}{ Working } & \multirow{2}{*}{$\mathrm{OR}_{\mathrm{adj}}$} & \multirow{2}{*}{$95 \% \mathrm{Cl}$} \\
\hline & $\%$ & p-value & & \\
\hline \multicolumn{5}{|c|}{ Psychosocial aspects } \\
\hline \multicolumn{5}{|l|}{ Close friends } \\
\hline None & 18.0 & & 1.00 & \\
\hline One and more & 12.9 & $<0.0001$ & 0.78 & $0.68-0.90$ \\
\hline \multicolumn{5}{|l|}{ Feeling lonely in the past 12 months } \\
\hline Never/rarely & 12.9 & & 1.00 & \\
\hline Sometimes, most of the time, always & 13.9 & $=0.02$ & 1.26 & $1.17-1.36$ \\
\hline \multicolumn{5}{|c|}{ Frequency of difficulty sleeping in the past 12 months } \\
\hline Never/rarely & 12.7 & & 1.00 & \\
\hline Sometimes, most of the time, always & 16.1 & $<0.0001$ & 1.46 & $1.34-1.60$ \\
\hline
\end{tabular}

$1.34-1.60)$, and lower chances of having close friends (OR $=0.78 ; 95 \%$ CI $0.68-0.90)$. Students who worked had more chances of practicing physical activities during leisure time for five days a week or more in the past seven days in comparison to those who do not work (Table 3 ).

\section{DISCUSSION}

This study was conducted with $9^{\text {th }}$ graders, from elementary school in the daytime period of public and private Brazilian schools, and it showed that $13.1 \%$ of them reported working, and that work has been associated with worse social indicators. The prevalence of work was extremely high, considering a sample of students who attended school. The results in this study point out that adolescents who worked presented risk behaviors, such as smoking and consumption of alcohol and other drugs, more frequently, and they were also more exposed to violence and psychosocial problems, such as sleeping disorders and social isolation, when compared to the ones who did not work, regardless of age and sex. The findings in this study suggest that working at early stages of life is an important marker for social vulnerabilities concerning health.

The prevalence of work among adolescents ranges a lot due to the criteria used to define work, the considered age group and the social context of each studied population. Therefore, the comparison of estimates is limited. In the United States, $13.5 \%$ of the students aged 14 to 18 years old who lived in the state of Wisconsin were working in $2003^{19}$. The frequency of seasonal jobs in the summer, among students aged 10 to 14 years old in the same American state in 2001, was 
of $58 \%{ }^{20}$. In Brazil, the prevalence of work among students in public schools aged from 10 to 19 years old in cities in the countryside of São Paulo, in 1998, was of $70 \%{ }^{21}$, while this proportion for adolescents in the same age group living in the city of Pelotas (Rio Grande do Sul State), in that same year, was of $17 \%{ }^{16}$. Among adolescents in the birth cohort of 1993, in the city of Pelotas, who were interviewed in 2008, 22\% reported having worked in the past year ${ }^{22}$.

For children and adolescents who work, especially in family enterprises and in the household, seasonality is frequent, and there is major variability in the number of working hours. Informality, the exercise of unregulated work, with no legal guarantees, is an usual characteristic, which makes this group even more vulnerable ${ }^{23}$. We do not have data to characterize the work of the analyzed adolescents. The reports of activities can be very different in relation to aspects such as regularity, workload and formality. On the other hand, the information was provided by the students themselves, being less subject to any sort of constraint.

The Brazilian law establishes that the minimum age to enter the work market is 16 years old. A job that can cause any damage to health is allowed after the age of 18. Adolescents aged between 14 and 15 years old can only work as apprentices ${ }^{4}$. Despite the established legal limitations, $11 \%$ of the adolescents who worked with wages were up to 13 years old, which shows the non-observance of legal limitations. The violation of law is also observed in other countries, including developed ones ${ }^{24}$. It is possible that legal restrictions could partly explain the increasing chances of working with the increment of age.

One of the main motivations for work among children and adolescents is poverty ${ }^{23,25}$. The work of children and adolescents can contribute with an effective improvement in family incomes ${ }^{7}$. However, being exposed to labor early is also influenced by cultural aspects, for belonging to migrant and monoparental families ${ }^{26}$, or due to the existence of family business and paternal schooling ${ }^{25}$. More than half of the students who worked received some sort of earning, and the only statistically significant difference between them and the ones who were not paid was the higher attendance to public schools. We also observed that the chance of working, regardless of earnings, was lower among those whose parents had incomplete higher education and for those who studied in private schools. These results may suggest that the work of these adolescents may have some importance for family income.

As to gender differences concerning the insertion in the work market, girls had less chances of working than boys, as observed in other studies ${ }^{7,22}$. The act of working among girls tends to be underestimated, since they do household chores more often ${ }^{22}$; this is almost an invisible activity, even for the girls. We also observed that adolescents who reported being indigenous and yellow had more chances of working than the others regardless of macroregion of residency.

The relationship between working at an early age and health has been little studied. The compromising of health does not only involve the direct effects over the current and future health status, but also the well-being and the development of potentialities in children and adolescents. A broad approach of the relationship between working at early ages and health damage should consider both the risks of the environment and the conditions of work, and also the potential effects over behaviors related to health and psychosocial aspects. 
One of the most analyzed aspects of the relationship between health and work among adolescents concerns accidents, which are considered as a public health issue in this age group. Teenagers are more vulnerable than adults when it comes to work-related risks, since they are going through physical and psychological development ${ }^{5}$. It is believed that the non-observance of age specificities, such as the circadian rhythm pattern, the adoption of inadequate supervision practices and the lack of training can explain part of these accidents ${ }^{23}$. A study with teenagers aged 16 to 24 years old who were formally inserted in the Brazilian work market identified that being on leave due to work accidents was more common for teenagers, aged between 16 and 19 years old ${ }^{27}$. An analysis in this study identified that students who worked had higher chances of being injured in the past 12 months than those who did not work, regardless of sex and age group.

Behaviors such as the use of licit and illicit drugs and sexual activity, which usually initiate in the transition from childhood to adulthood, are influenced by the social and the cultural contexts, by family and school environment and by relationships with peers ${ }^{28,29}$. The early exposure to labor may stimulate maturity and lead to the adoption of roles that are fit for adults, such as the adoption of unhealthy behaviors and the formation of a new family ${ }^{30}$. It is also suggested that due to the intensity of work, adolescents have more time for social unwanted activities, and also that they have less time to engage in healthy behaviors and school activities ${ }^{31}$. Adolescents who worked presented higher chances of smoking, using alcohol and illicit drugs, driving motorized vehicles, having sexual intercourse and being more exposed to violent situations as observed in other studies ${ }^{16,28,32,33}$. It is important to consider that these behaviors tend to take place simultaneously, so the insertion of one of them would increase the risk for the others, thus potentializing the adverse effects of work among adolescents ${ }^{28,34}$.

Children and adolescents who work have less time for family and social relationships, for recreation or rest, and also difficulties to combine work and school ${ }^{23}$. Sleeping problems are common, especially among those who work 20 hours a week or more ${ }^{12}$. Both tasks, school and work, can contribute with reduced time for sleeping, which leads to the perception of chronic tiredness, difficulties concentrating and abstract thinking, with damages for school performance and higher risk of accidents ${ }^{10}$. Data in this study suggest that work has a negative impact on the quality of sleep, and that it favors social isolation for adolescents, once they felt lonely more often and had less chances of having close friends. Besides, there is the fact that they were involved in more fights and were more assaulted than those who did not work. Therefore, the disadvantages related to work can act in synergy. Socioeconomic disadvantages increase the chances of early exposure to labor, which, on the other hand, it associated with the use of psychoactive substances and other risk behaviors, with social problems and difficulties at school, as well as to discussions with peers, thus contributing with higher risk of abuse of substances, which feeds a cycle of disadvantages ${ }^{35}$.

This analysis did not aim at identifying the cause-effect relation, nor to identify independent associations, since the estimated Odds Ratio was adjusted only for age and sex. 
However, it is difficult to think of reverse causality when it comes to work, since it is unlikely that risk behaviors will lead the student to work. However, it is probable that work and risk behaviors express the same scenario of social and economic vulnerability, which is becomes a cycle with time.

\section{CONCLUSION}

To sum up, our data enable to conclude that adolescents who study and work go through exposures that can affect difference health dimensions. Exposure to work at an early age is associated with health damaging behaviors, violent situations, sleeping disorders and social isolation. These, on the other hand, tend to have a negative impact on school performance, thus leading to disadvantages throughout life. Besides, the adverse circumstances of childhood and adolescence are associated with the worse evaluation of health in the adult life. Efforts to fight work in early stages of life should be re-established.

\section{REFERENCES}

1. Bureau Internacional do Trabalho. Programa Internacional para a Eliminação do Trabalho Infantil (IPEC). Medir o progresso na Luta contra o Trabalho Infantil - Estimativas e tendências mundiais 2000-2012. Genebra; 2013 (OIT).

2. Instituto Brasileiro de Geografia e Estatística. Pesquisa Nacional por Amostra de Domicílios: Trabalho infantil. Rio de Janeiro; 2001 (IBGE).

3. Instituto Brasileiro de Geografia e Estatística. Pesquisa Nacional por Amostra de Domicílios. Síntese de Indicadores. Rio de Janeiro; 2012 (IBGE).

4. Barros RP, Mendonça R. Trabalho Infantil no Brasil: rumo à erradicação. Texto para Discussão: 1506. Brasília; 2010 (IPEA).

5. Gonzales, KA, Perez RQ, Contreras MY. Determinantes y consecuencias del trabajo infantil: um análisis de la literatura. Rev Fac Cienc Econ 2011; 21(1): 113-24.

6. Carvalho JC, Marinho E, Loria F. Idleness, Returns to Education and Child Labor. Rev Bras Econ 2012; 66(4): 405-27.

7. Facchini AL, Fassa AG, Dall'Agnol AD, Maia MFS. Trabalho infantil em Pelotas: perfil ocupacional e contribuição à economia. Ciên Saúde Coletiva 2003; 8(4): 953-61.

8. Barreto SM, Carvalho RF, Giatti L. Socioeconomic inequalities in youth smoking in Brazil. BMJ Open 2013; 3(12): e003538.
9. Braveman P, Barclay C. Health Disparities Beginning in Childhood: A Life-Course Perspective. Pediatrics 2009; 124(3): S163-75.

10. Fischer FM, Oliveira DC, Teixeira LR, Teixeira MCTV, Amaral MA. Efeitos do trabalho sobre a saúde do adolescente. Ciên Saúde Coletiva 2003; 8(4): 973-84.

11. Fassa AG, Facchini LA, Dall'Agnol MM, Christiani DC. Child labor and musculoskeletal disorders: the Pelotas (Brazil) epidemiological survey. Public Health Rep 2005; 120(6): 665-73.

12. Wegmann D. Child labor in US. Ciên Saúde Coletiva 2003; 8(4):1029-37.

13. Rohlman DS, Nuwayhid I, Ismail A, Saddik B. Using epidemiology and neurotoxicology to reduce risks to young workers. Neurotoxicology 2012; 33(4): 817-22.

14. Esin MN, Bulduk S, Ince H. Workrelated risks and health problems of working children in urban Istanbul, Turkey. J Occup Health 2005; 47(5): 431-6.

15. Benvegnú LA, Fassa AG, Facchini LA, Wegman DH, Dall'Agnol MM. Work and behavioural problems in children and adolescents. Int J Epidemiol 2005; 34(6): 1417-24.

16. Dall'Agnol MM, Fassa AG, Facchini LA. A associação entre trabalho de crianças e adolescentes e tabagismo: um estudo transversal no sul do Brasil. Cad Saúde Pública 2011; 27(1): 46-56. 
17. Brasil. Instituto Brasileiro de Geografia e Estatística. Pesquisa Nacional de Saude do Escolar - PeNSE 2012. Rio de Janeiro: IBGE; 2013.

18. World Health Organization. Inequalites in young people's health: Health Behavior in School-aged Children. International Report from 2005-2006. Geneva: WHO; 2008. (Health Policy for Children and Adolescents, No. 5)

19. Zierold KM, Appana S, Anderson HA. Students Enrolled in School-Sponsored Work Programs: The Effect of Multiple Jobs on Workplace Safety and School-Based Behaviors. WMJ 2011; 110(4): 171-7.

20. Zierold KM, Garman S, Anderson H. Summer work and injury among middle school students, aged 10-14 years. Occup Environ Med 2004; 61(6): 518-22.

21. Martins IS, Fischer FM, Oliveira DC, Teixeira LR, da Costa LAR, Marinho SP, et al. Crescimento e trabalho de estudantes de ensino fundamental e médio em São Paulo, Brasil. Rev Saúde Pública 2002; 36(1): 19-25.

22. Gonçalves H, Menezes AMB, Bacchieri G, Dilélio AS, Bocanegra CAD, Castilhos ED, et al. Perfil de trabalho urbano de adolescentes de 14-15 anos: um estudo populacional no Sul do Brasil. Ciên Saúde Coletiva 2012; 17(5): 1267-74.

23. World Health Organization. Child Labour \& Adolescent Workers. The Global Occupational Health Network, Issue no. 9. Geneva; 2005.

24. Dal Santo JA, Bowling JM, Harris TA. Effects of Work Permits on Illegal Employment Among Youth Workers: Findings of a School-Based Survey on Child Labor Violations. Am J Public Health 2010; 100(4): 635-7.

25. Cacciamali MC, Tatei F. Trabalho infantil e o status ocupacional dos pais. Rev Econ Polít 2008; 28(2):269-90.

26. Batista NF, Cacciamali MC. Migração familiar, trabalho infantil e ciclo intergeracional da pobreza no estado de São Paulo. Nova Econ 2012; 22(3): 515-54.
27. Sousa Santana V, Villaveces A, Bangdwala SL, Runyan $\mathrm{CW}$, Albuquerque Oliveira PR. Incidence of severe work-related injuries among young adult workers in Brazil: analysis of compensation data. Inj Prev 2012; 18(4): 221-7.

28. Barreto SM, Giatti L, Casado L, de Moura L, Crespo C, Malta D. Contextual factors associated with smoking among Brazilian adolescents. J Epidemiol Community Health 2012; 66(8): 723-9.

29. Barreto SM, Giatti L, Martinez Hernaez A. Contextual and family factors associated with negative assessment of children's health. Eur J Public Health 2011; 21(5): 649-55.

30. Staff J, Vaneseltine M, Woolnough A, Silver E, Burrington L. Adolescent Work Experiences and Family Formation Behavior. J Res Adolesc 2012; 22(1): 150-64.

31. Safron DJ, Schulenberg JE, Bachman JG. Part-time work and hurried adolescence: the links among work intensity, social activities, health behaviors, and substance use. J Health Soc Behav 2001; 42(4): 425-49.

32. McMorris BJ, Uggen C. Alcohol and employment in the transition to adulthood. J Health Soc Behav 2000; 41(3): 276-94.

33. Wu LT, Schlenger WE, Galvin DM. The relationship between employment and substance use among students aged 12 to 17. J Adolesc Health 2003; 32(1): 5-15.

34. Oliveira-Campos M, Giatti L, Malta D, Barreto SM. Contextual factors associated with sexual behavior among Brazilian adolescents. Ann Epidemiol 2013; 23(10): 629-35.

35. Bowes L, Chollet A, Fombonne E, Galéra C, Melchior M. Lifecourse SEP and tobacco and cannabis use. Eur J Public Health 2013; 23(2): 322-7.

Received on: 12/10/2013

Final version presented on: 04/01/2014

Accepted on: 04/15/2014 
DOI: 10.1590/1980-5497201500004001

\section{CORRECTIONS / ERRATA}

Rev. bras. epidemiol. vol.17 supl.1 São Paulo 2014

http: / / dx.doi.org/ 10.1590/1809-4503201400050003

Volume 17, número Suplemento 1, 2014

Labor in early life, vulnerability for health in Brazilian schoolchildren: National Adolescent School-based Health Survey (PeNSE 2012)

Trabalho precoce, marcador de vulnerabilidades para saúde em escolares brasileiros: Pesquisa Nacional de Saúde do Escolar (PeNSE 2012)

Where it read:

- Sandy Maria Barreto

Now it reads:

- Sandhi Maria Barreto 